\title{
衝撃波離脱距離計測による高温衝撃風洞流れの酸素原子の検定*
}

\author{
伊藤勝宏 ${ }^{* 1}$ ，橋本時忠 ${ }^{* 2}$, 小室智幸 ${ }^{* 3}$, 丹野英幸 ${ }^{* 1}$, 佐藤和雄 ${ }^{* 1}$, 高橋政浩 ${ }^{* 1}$, 小寺正敏 ${ }^{* 1}$
}

\section{Calibration of Oxygen Atom Mass Fraction in High Enthalpy Shock Tunnel Flow Based on Shock Stand-off Distance Measurement}

\author{
Katsuhiro ITOH ${ }^{* 1}$, Tokitada HASHIMOTO, Tomoyuki KOMURO, Hideyuki TANNO, \\ Kazuo SATO, Masahiro TAKAHASHI and Masatoshi KODERA \\ ${ }^{* 1}$ Japan Aerospace Exploration Agency \\ Koganesawa 1, Kimigaya, Kakuda, 981-1525 Japan
}

In the present paper, an attempt was made on calibrating mass fraction of oxygen atom which can exist in a free stream of a high enthalpy shock tunnel based on a measurement of shock stand-off distance. To correlate the free stream oxygen atom and the shock stand-off distance, a density relaxation function was derived by considering an effect of the free stream oxygen atom on density change along stagnation stream line behind the shock wave. The density relaxation function was numerically estimated with the mass fraction of oxygen atom predicted by using NENZF code and used to examine the correlation with the shock stand-off distance around the sphere model measured in the high enthalpy shock tunnel HIEST at JAXA Kakuda Space Center. The correlation between the density relaxation function considering the effect of free stream oxygen atom and the shock stand-off distance was successfully obtained, as the result the mass fraction of oxygen atom in the free stream of the HIEST could be calibrated.

Key Words : Compressible Flow, Hypersonic Flow, Real Gas Effect, Shock Wave, Flow Visualization

\section{1. 緒言}

超音速流中に置かれた鈍頭形状物体の前方には弓状衝撃波が形成され, 鈍頭部の曲率半径, 衝撃波前後の密度 跳踓，および衝撃波から物体までの密度変化によって物体から衝撃波が離脱する距離，いわゆる衝撃波離脱距離 が決まる. 特に極超音速流れでは, 気体の運動エネルギーの多くが衝撃波によって内部エネルギーに変換される ので, 衝撃波から物体までの密度変化に対する運動エネルギー変化の寄与は小さく, 衝撃波離脱距離は内部エネ ルギー変化を伴う化学反応に最も強く依存する. 一般に, 衝撃波上流の流速が高くなるほど衝撃波下流が高温と なって分子の解離反応が顕著となり, 解離反応による吸熱が温度低下とともに密度増加をまねき, 衝撃波離脱距 離が短くなる傾向がある. 本研究では, このような化学反応と衝撃波離脱距離の関係に着目し, 直接計測するこ とが困難な高温衝撃風洞の流れの化学組成について, 衝撃波離脱距離の可視化計測を利用した間接的な検証を試 みる。

高温衝撃風洞は, 大気圈に再突入する機体まわりの高温流れを地上で再現できる最も有力な風洞である. 大気 圈に再突入する機体まわりの流れは 1 万度ほどの高温となり, 機体が受ける熱負荷や空力特性が酸素や窒素の解 離反応を主とする化学反応に影響される. このような化学反応を伴う大気圈再突入流れを風洞で再現するには, 速度，温度，およびバイナリースケーリングパラメータ（密度と代表長さの積）を飛行条件に一致させなければ ならず, 十分な大きさの高温衝撃風洞が唯一の実現可能な風洞である. しかし高温衝撃風洞の流れは, 衝撃波管

* 原稿受付 2010 年 6 月 10 日

*1 正員, (独)宇宙航空研究開発機構（干981-1525 宮城県角田市君萱字小金沢 1)

*2 正員, 佐賀大学 理工学部（广840-8502 佐賀県佐賀市本庄町 1)

*3 (独) 宇宙航空研究開発機構

E-mail: ito.katsuhiro@jaxa.jp 
端で反射した衝撃波背後で一度淀んでからノズルで加速膨張するため, 反射衝撃波背後の解離反応で生じた原子 の再結合がノズル内で十分進まず, 未再結合のまま原子が主流に残留する場合がある. 宇宙航空研究開発機構 (JAXA)が有する世界最大の高温衝撃風洞 HIEST ${ }^{(1)}$ においても, 比較的密度の低い試験条件ではノズル内の酸素 原子の再結合反応が遅くて主流に残留すると考えられ, 未再結合酸素原子の試験データへの影響が懸念されてい る. 高温衝撃風洞の主流に残留する酸素原子を直接計測するのは容易ではなく, 未だその影響を正確に把握でき ていないのが現状である. そこで本研究では, 可視化計測が可能な衝撃波離脱距離の化学反応に対する感度に着 目し, 高温衝撃風洞 HIEST の試験部に設置した球模型まわりの衝撃波離脱距離の計測結果を利用した, 主流酸素 原子の質量分率の同定を試みた. HIEST の主流において残留が疑われる酸素原子と衝撃波離脱距離の関係を明確 にするため, 本研究では淀み点エンタルピと主流の密度について広範囲に試験条件を設定し, 半径の異なる $3 つ$ の球模型を用いて試験を行い, シュリーレン写真より衝撃波離脱距離を計測した. 衝撃波離脱距離を決定する主 要因と考えられる, 主流酸素原子の影響を考慮した衝撃波背後の密度勾配関数を導出し ${ }^{(2)}$, 準 1 次元化学非平衡 流解析 ${ }^{(3)}$ で予測した主流酸素原子の質量分率を用いて密度勾配関数を数值化し, 衝撃波離脱距離の計測結果との 相関関係を検証することによって主流酸素原子の質量分率の同定を試みた. その結果, 広範囲の試験条件につい て計測結果と予測值による密度勾配関数の間に良好な相関関係が得られ, 理論と予測值の妥当性を検証すること によって主流に残留する酸素原子の質量分率を同定した.

\section{2. おもな記号}

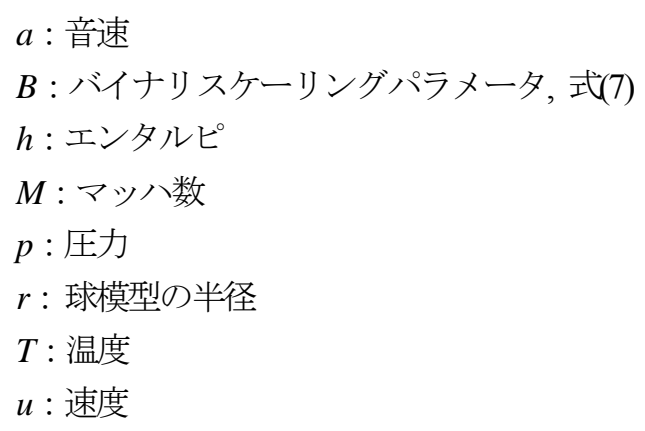

$\alpha:$ 未再結合原子の質量分率

$\Delta$ : 衝撃波離脱距離

$\rho:$ 密度

$\Pi:$ 標準化した衝撃波離脱距離

$\theta_{d}:$ 解离倠特性温度

$\Omega:$ 密度勾配関数 $\frac{r}{\rho_{s} U_{\infty}}\left(\frac{d \rho}{d t}\right)_{s}$

$\omega$ : 酸素解離反応の緩和関数

\section{3. 極超音速流れにおける衝撃波離脱距離}

衝撃波離脱距離は, 衝撃波と物体の間で流れがじれだけ圧縮されるかによって決まり，以下のように衝撃波と 物体の間の平均密度に関係づけられる.図 1 に示すように, 物体の淀み点近傍半径 $x$ の検查面 $\pi x^{2}$ に流入する質量 流量を $\pi x^{2} \rho_{\infty} U_{\infty}$, 検查体積における平均密度を $\rho_{b}$ として検査面 $2 \pi x \Delta$ から流出寸る質量流量を $2 \pi x \Delta \rho_{b} u_{b}$ と表わし, 検査体積における質量保存を考える.

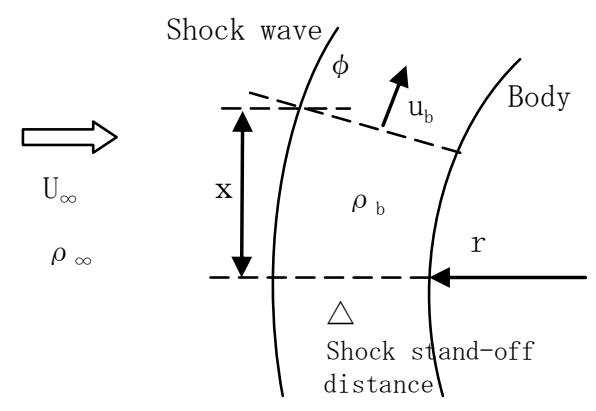

Fig. 1 Shock stand-off distance. 
極超音速流れでは衝撃波離脱距離が十分短いので, $u_{b} \doteqdot U_{\infty} \cos \phi^{(2)}, x \doteqdot r \cos \phi$ として半径 $x$, 長さ $\Delta$ の検查体積 に流入・流出する質量流量を等值すれば, 以下のような平均密度 $\rho_{b}$ と $\Delta$ の関係が得られる.

$$
\frac{\rho_{b}}{\rho_{\infty}} \frac{\Delta}{r} \approx \frac{1}{2}
$$

もちろん右辺の $1 / 2$ は厳密な值ではないが, 過去の多くの解析によれば (4), (5) など, 右辺がほぼ一定值となって衝 撃波離脱距離がほとんど平均密度のみに依存することが理論的に予測されている. 以下, 衝撃波前後の密度比と 衝撃波下流（衝撃波から物体までの流れ）の密度変化に分けて平均密度について考える.

Lighthill の Ideal dissociating gas ${ }^{(6)}$ を仮定すれば, 極超音速流れにおける垂直衝撃波前後の密度比は,

$$
\frac{\rho_{s}}{\rho_{\infty}} \approx \frac{2\left(4+\alpha_{\infty}\right)}{1+\alpha_{\infty}}
$$

と与えられる.ここに添え字のおよび $\mathrm{s}$ は, 主流および衝撃波直後の状態を表わす. 式(2)によれば, 主流の未再結 合原子 $\alpha_{\infty}$ が増えるほど密度比が小さくなり，衝撃波離脱距離が長くなると考えられる.

衝撃波下流の密度変化については, 極超音速流れの場合, 衝撃波によって多くの運動エネルギーが内部エネル ギーに変換されるので, 分子振動, 電子励起および化学反応などの内部エネルギー状態の変化が支配的となる. 本研究では, 化学反応の影響が他に比べて十分大きくなる気流条件を扱うので, 以下, 化学反応の効果に絞って 考える. 状態方程式 $h=h\left(p, \rho, \alpha_{i}\right)$ より, エンタルピ変化 $d h$ は以下のように書ける.

$$
d h=h_{p} d p+h_{\rho} d \rho+\sum h_{\alpha_{i}} d \alpha_{i}
$$

衝撃波から物体までの流れにおいては, 運動エネルギーが内部エネルギーに比べて十分小さく,

$$
\frac{u^{2}}{a_{\text {frozen }}^{2}}=M_{f}^{2}\langle<1
$$

であるから，エネルギー式と運動方程式より，

$$
\begin{gathered}
\frac{d h}{h}=-\frac{u^{2}}{h} \frac{d u}{u}=-M_{f}^{2} \frac{a_{f}^{2}}{h} \frac{d u}{u} \approx O\left(M_{f}^{2}\right) \\
\frac{d p}{p}=-\frac{\rho u^{2}}{p} \frac{d u}{u}=-M_{f}^{2} \frac{\rho a_{f}^{2}}{p} \frac{d u}{u} \approx O\left(M_{f}^{2}\right)
\end{gathered}
$$

したがって密度変化 $d \rho$ は,

$$
d \rho \approx-h_{\rho}{ }^{-1} \sum h_{\alpha_{i}} d \alpha_{i}
$$

となり，ほとんど化学反応に伴うエネルギー変化のみに関係することがわかる.

本研究で衝撃波離脱距離の計測に用いる球模型の大きさ, および淀み点エンタルピと密度の範囲では, 衝撃波 から模型までの流れは典型的な化学非平衡流れとなり, 経験的に 1 次式で密度変化が近似される ${ }^{(2)}$. したがって 衝撃波直後の密度と密度勾配だけで平均密度を近似できるので, 衝撃波離脱距離を衝撃波前後の密度比で標準化 すれば, 衝撃波直後の密度勾配によって衝撃波離脱距離がほぼ決まると考えられる. 本研究で衝撃波離脱距離の 計測を行う淀み点エンタルピの範囲では, 酸素の解離反応によるエネルギー吸収が他の反応エネルギーの寄与に 比べて圧倒的に大きいので, 酸素の解離反応のみを考慮し, 式(4)より以下のように衝撃波直後の密度勾配関数 $\Omega$ $\left(=(d \rho / d t)_{s}\left(r / \rho_{s} U_{\infty}\right)\right)$ を導出した. 


$$
\begin{gathered}
\Omega(\alpha ; T, U, B)_{s}=\frac{1}{4+\alpha_{s}}\left(\frac{\theta_{d}}{T_{s}}-\frac{3}{1+\alpha_{s}}\right) \omega_{s} \\
\omega(\alpha ; T, U, B)_{s} \equiv \frac{r}{U_{\infty}}\left(\frac{d \alpha}{d t}\right)_{s}=\frac{B}{U_{\infty}} C T_{s}^{\eta} \frac{\rho_{s}}{\rho_{\infty}}\left[\left(1-\alpha_{N_{2}}-\alpha_{s}\right) e^{-\theta_{d} / T_{s}}-\frac{\rho_{s} \alpha_{s}^{2}}{\rho_{d}}\right] \\
B \equiv \rho_{\infty} r
\end{gathered}
$$

ここで $\alpha$ は酸素原子の質量分率を示し, 薄い衝撃波内部では化学反応は進行しないので $\alpha_{s}=\alpha_{\infty}$ となる. $\theta_{d}$ は酸 素の解離特性温度を示す。 $\omega$ は,模型半径で標準化した気流速度に対寸る反応速度の比を表わし, 主流の酸素原子, 温度,速度およびバイナリースケーリングパラメータ $B$ に依存寸る酸素解離反応の緩和関数である ${ }^{(7)} . \Omega$ は, 式(4) の反応速度と密度変化の関係に式(6)を代入して得られる密度勾配を, 衝撃波直後の密度 $\rho_{s}$ で標準化した密度勾配 関数である. 式(5)および(6)が示寸理論的な傾向は, 高温でバイナリースケーリングパラメータが大きいほど解離 反応が速くて密度勾配が大きくなり，したがって平均密度が増加して衝撃波離脱距離が短くなるというものであ る. また式(5)および(6)は, 主流に未再結合酸素原子 $\alpha_{\infty}\left(=\alpha_{s}\right)$ が存在すると衝撃波下流の反応速度を下げて密度勾 配を減少させ, 密度増加が抑制されて衝撃波離脱距離が長くなることを理論的に示している.

\section{4. 高温衝撃風洞 HIEST}

\section{$4 \cdot 1 \quad$ HIEST の概要}

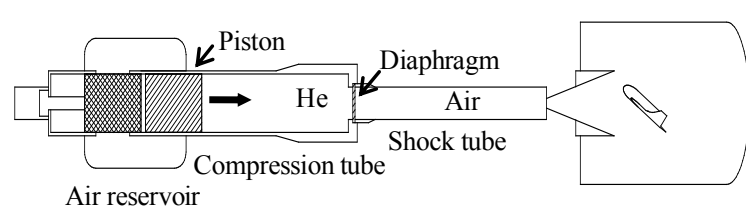

Fig.2 Schematic of high enthalpy shock tunnel.

HIEST は自由ピストン型の高温衝撃風洞であり，高圧空気貯気槽,圧縮管,衝撃波管，ノズルおよび試験部からな る. 高圧空気でピストンを加速し, 400 m/s 前後のスピードで圧縮管内のヘリウムガスを断熱的に圧縮し, ヘリウ ムガスの温度と圧力を最大 $4000 \mathrm{~K}$ および $150 \mathrm{MPa}$ まで上昇させる. ヘリウムガスが所定の圧力に達すると圧縮管 と衝撃波管を仕切っているステンレス製の隔膜が破断し, 衝撃波管内に非常に強い衝撃波を発生する. 衝撃波は 衝撃波管端で反射し, 反射衝撃波背後で一度淀み状態となった試験気体がノズルで加速膨張し, 試験部に設置し た模型まわりに高速の試験気流が形成される. HIEST の外観および基本諸元をそれぞれ図 3 および表 1 に示す.

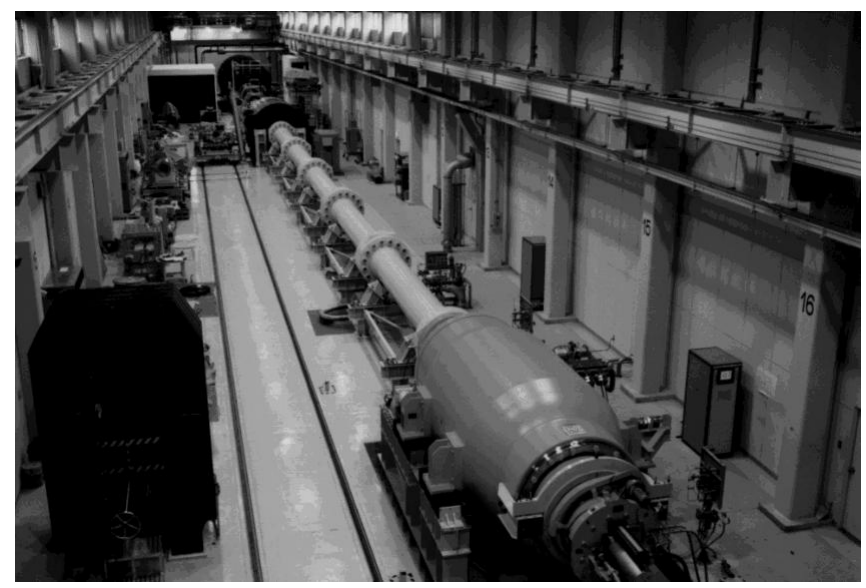

Fig.3 Overall view of the HIEST. 
Table 1 Description of the HIEST.

\begin{tabular}{lll}
\hline $\begin{array}{l}\text { Compression tube } \\
\text { Shock tube }\end{array}$ & $\begin{array}{l}\text { Length } 42 \mathrm{~m} \\
\text { Length } 17 \mathrm{~m}\end{array}$ & $\begin{array}{l}\text { Diameter } 600 \mathrm{~mm} \\
\text { Diameter } 180 \mathrm{~mm}\end{array}$ \\
$\begin{array}{ll}\text { Piston masses } & 220,290,440,580,780 \mathrm{~kg}\end{array}$ \\
$\begin{array}{ll}\text { Nozzle(conical) } & \text { Exit diameter } 1200 \mathrm{~mm} \\
\text { Throat diameter } 24 \text { to } 50 \mathrm{~mm}\end{array}$ \\
$\begin{array}{ll}\text { Nozzle(contoured) } & \text { Exit diameter } 800 \mathrm{~mm}\end{array}$ \\
$\begin{array}{ll}\text { Throat diameter } 50 \mathrm{~mm} \\
\text { Maximum stagnation enthalpy } & 25 \mathrm{MJ} / \mathrm{kg} \\
\text { Maximum stagnation pressure } & 150 \mathrm{MPa}\end{array}$ \\
Test time & $2 \mathrm{msec}$ or more \\
\hline
\end{tabular}

\section{$4 \cdot 2$ ノズル流れ}
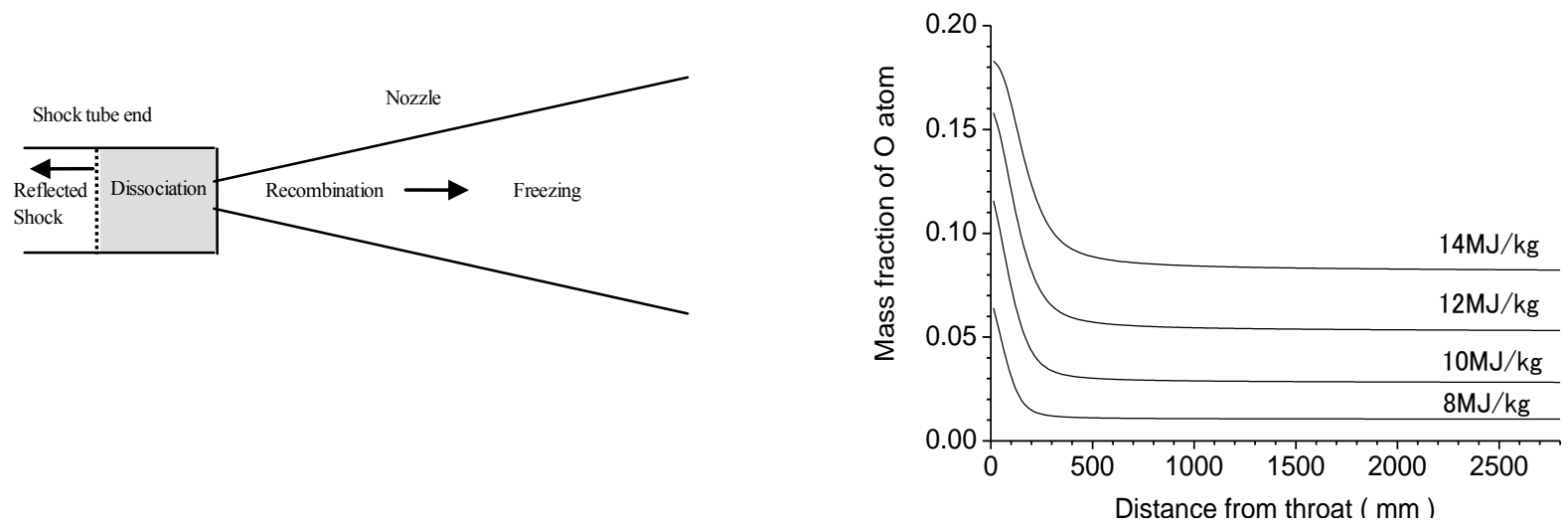

Fig. 4 Mass fraction of oxygen atom in the HIEST nozzle flow predicted by NENZF.

衝撃波管端で反射した衝撃波の背後には, 数千度から 1 万度ほどの高温の淀み点状態が形成され, 比較的解離 エネルギーが低い酸素分子のかなりの割合が解離する. 解離した酸素原子はノズルに流入すると再結合し始める が，ノズルの急な膨張によって再結合反応の凍結が起こり，ノズル出口に至っても未再結合のまま残留すること がある. 図 4 は, HIEST のコンターノズル（長さ $2.8 \mathrm{~m}$, 出口径 $800 \mathrm{~mm}$, 開口比 256 , 入り口半頂角 12.8 度）につい て, 熱平衡を仮定した準 1 次元化学非平衡流解析 NENZF コード(3)を用いて計算した各淀み点エンタルピ条件にお ける酸素原子の質量分率の変化を示す.いずれの場合も淀み点圧力は $20 \mathrm{MPa}$ である. 縦軸は酸素原子の質量分率, 横軸はスロートからの距離を示す. スロートにおける解離酸素の量は淀み点エンタルピとともに増加し, $14 \mathrm{MJ} / \mathrm{kg}$ の場合は $90 \%$ 以上の酸素が解離している. スロートを通過後しばらくは再結合反応が進み, 解離酸素の量が減少 する. しかしノズルの急な膨張によって流れが加速される一方で密度が低下し, 密度の二乗に比例する再結合反 応速度が流速に対して相対的に急低下寸るのでスロートから 200 300 mm あたりで再結合反応が進まなくなり， $500 \mathrm{~mm}$ を過ぎるといずれの淀み点エンタルピ条件においても凍結状態となる. 淀み点圧力を同一にした場合, 淀 み点エンタルピが高いほど密度が低く, かつ流速が大きいので未再結合のまま酸素原子が残留しやすい. 準 1 次 元化学非平衡解析では, 淀み点エンタルピが $14 \mathrm{MJ} / \mathrm{kg}$ の場合, 約 $40 \%$ の酸素が未再結合状態でノズル出口の主流 に残留すると予測されている. 


\section{5. 試験条件}

Table 2 Nominal test condition and mass fraction of atomic oxygen predicted by NENZF.

\begin{tabular}{|c|c|c|c|c|}
\hline $\begin{array}{c}\mathrm{B}_{\text {(nominal) }} \\
\mathrm{kg} / \mathrm{m}^{2}\end{array}$ & $\begin{array}{c}r \\
\mathrm{~mm}\end{array}$ & $\begin{array}{c}\rho \text { (nominal) } \\
\mathrm{kg} / \mathrm{m}^{3}\end{array}$ & $\begin{array}{c}\mathrm{H}_{0} \text { (nominal) } \\
\mathrm{MJ} / \mathrm{kg}\end{array}$ & $\begin{array}{c}\alpha_{\infty} \\
\text { Mass fraction }\end{array}$ \\
\hline $2 \times 10^{-4}$ & 25 & 0.008 & 10 & 0.031 \\
& 40 & 0.005 & 12 & 0.061 \\
& 50 & 0.004 & 14 & 0.086 \\
\hline $4 \times 10^{-4}$ & 25 & 0.016 & $4,6,8$ & $0.00 \sim 0.012$ \\
& 40 & 0.010 & $6,8,10,12$ & $0.005 \sim 0.032$ \\
& 50 & 0.008 & 10 & 0.03 \\
\hline $8 \times 10^{-4}$ & 25 & 0.032 & 8 & 0.002 \\
& 40 & 0.020 & 8 & 0.002 \\
& 50 & 0.016 & 8 & 0.011 \\
\hline
\end{tabular}

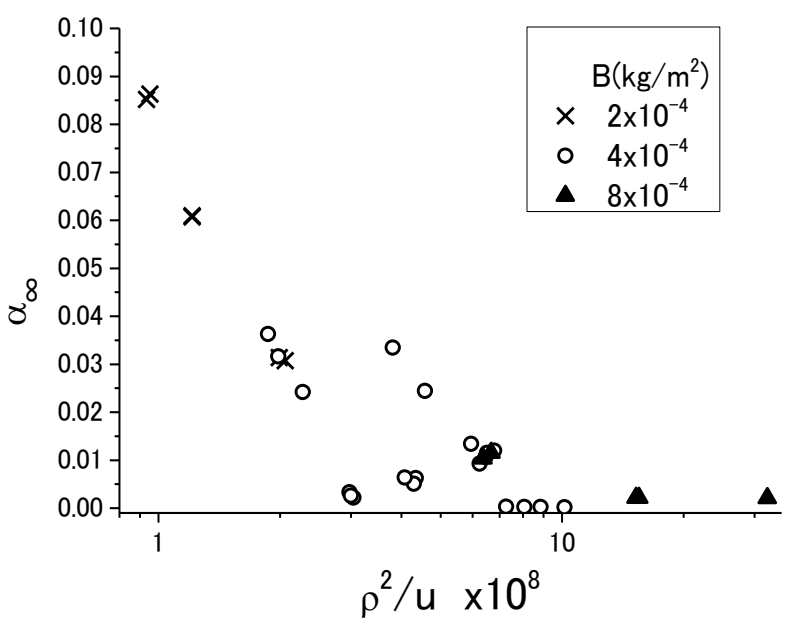

Fig. 5 Mass fraction of oxygen atom in the the free stream of the HIEST predicted by NENZF.

本研究では, 直接計測することができない未知の物理量の同定, 理論および数值解析の妥当性の検証という 3 つの課題を同時に解くことで目的の主流検定を試みる. そのため,基本となるパラメータについて適切に条件マト リクスを設定して試験と解析を行うことが重要となる. 衝撃波離脱距離を決定する主要因として導出した式(5)の 密度勾配関数に示したように, 対象となるパラメータは温度, 流速, バイナリースケーリングパラメータ, および 主流の酸素原子質量分率の 4 つである. それに対し, 試験パラメータとして HIEST 試験でコントロールできるの は淀み点エンタルピ, 淀み点圧力および模型サイズの 3 つである. 前節で示したコンターノズルでノズル形状が 固定されるので, 淀み点エンタルピの設定で主流の温度と流速が決まってしまう. バイナリースケーリングパラ メータと主流の酸素原子質量分率は, 淀み点圧力と模型サイズによって独立に調節可能である.したがって HIEST 試験では, 淀み点エンタルピ,バイナリースケーリングパラメータおよび主流の酸素原子質量分率を基本 パラメータとして選択し, 表 2 に示すように条件マトリクスを設定した. 表 2 中の主流の密度および酸素原子質量 分率は, 準 1 次元化学非平衡流解析による予測值である. 3 通りのバイナリースケーリングパラメータについて, それぞれ半径の異なる 3 つの球模型を用い, 淀み点圧力の設定で密度を調節することによりバイナリースケーリ ングパラメータとは独立に主流の酸素原子質量分率を変化させた. このような条件マトリクスの設定により, バ イナリースケーリングパラメータの効果とは独立に主流の酸素原子の影響を考察することができる. 実際バイナ リスケーリングパラメータ $\mathrm{B}=4 \times 10^{-4}$ およ゙ $8 \times 10^{-4} \mathrm{~kg} / \mathrm{m}^{2}$ については, 淀み点エンタルピを固定して淀み点圧力の設 定だけで主流の酸素原子質量分率を変えることができ, 主流の酸素原子の影響を完全に独立にすることができた. しかし $\mathrm{B}=2 \times 10^{-4} \mathrm{~kg} / \mathrm{m}^{2}$ については, $15 \mathrm{MPa}$ という HIEST の淀み点圧力下限の制約のため, 淀み点エンタルピの設定 を変えることで密度を調節しなければならず, 主流の酸素原子の影響を完全に独立にすることはできなかった。

表 2 に示したノミナルの試験条件についてそれぞれ 2 回の試験を行い, 衝撃波離脱距離を計測した. 実際の HIEST における試験では, 隔膜破断圧のばらつきなどによって淀み点エンタルピや淀み点圧力がノミナル值とは 多少異なる. 特にノミナルの淀み点エンタルピ $8 \mathrm{MJ} / \mathrm{kg}$ については, 20MPaから $60 \mathrm{MPa}$ までの広範囲におよぶ淀み 点圧力設定による衝撃波減衰率の違いなどの影響のため, 実際の淀み点エンタルピは $7.0 \mathrm{MJ} / \mathrm{kg}$ から 9.0MJ/kg まで 変化する. 実測の淀み点エンタルピと淀み点圧力をもとに準 1 次元化学非平衡解析で計算した主流の酸素原子質 量分率の傾向を図 5 に示寸. 主流の酸素原子質量分率を縦軸, 再結合反応の相対速度が比例する主流の $\rho 2 / \mathrm{u}$ を横 軸にとった. 図中，×，○およびムはそれぞれバイナリースケーリングパラメータ $\mathrm{B}=2 \times 10^{-4}, 4 \times 10^{-4} \mathrm{~kg} / \mathrm{m}^{2}$ ，および $8 \times 10^{-4} \mathrm{~kg} / \mathrm{m}^{2}$ の場合の酸素原子の質量分率を示寸. 全体的には, 大きなバイナリースケーリングパラメータの場合 ほど密度を高く設定するので再結合反応が速く, 主流の酸素原子の質量分率が下がる傾向にある. 同一のバイナ リースケーリングパラメータであっても, 半径が小さい模型の場合ほど密度を高く設定するので再結合反応が速 
く, 主流の酸素原子の質量分率が低くなる.したがって $\mathrm{B}=4 \times 10^{-4}$ およ゙ $8 \times 10^{-4} \mathrm{~kg} / \mathrm{m}^{2}$ の模型半径 $25 \mathrm{~mm}$ の場合には, 主流にほとんど酸素原子が残留しないという予測結果になっている. 逆に $\mathrm{B}=2 \times 10^{-4} \mathrm{~kg} / \mathrm{m}^{2}$ の模型半径 $50 \mathrm{~mm}$ の場合 には, 密度の設定値が最も低く, $40 \%$ 以上の酸素が再結合せずに残留すると予測されている. なお $\mathrm{B}=4 \times 10^{-4} \mathrm{~kg} / \mathrm{m}^{2}$, 模型半径 25 および $40 \mathrm{~mm}$ の場合には, バイナリースケーリングパラメータと密度を固定して淀み点エンタルピを 変え, 主流の酸素原子に対する淀み点エンタルピの影響を確認できるようにした。

\section{6. 結果と考察}

\section{6・1シュリーレン写真による衝撃波離脱距離計測および淀み点エンタルピの効果}

HIEST のノズル下流に接続された試験部に球模型を設置し，レーザーシュリーレン法により模型前方の衝撃波 を可視化した. 光源には Spectra Physic 社の CW Green 固体レーザ(露光時間 30ns), 撮影には Nikon D200 を用いた. 衝撃波離脱距離は写真から直接計測した（衝撃波離脱距離の解像度は 60〜200 ピクセル/ $\Delta \square$, 計測精度 $\pm 2 \%$, 衝 撃波の時間変動土 $2 \%$ 以内). 図 6 は, 淀み点エンタルピ $10 \mathrm{MJ} / \mathrm{kg}$, 淀み点圧力 $20 \mathrm{MPa}$, およびバイナリースケーリ ングパラメータ $4 \times 10^{-4} \mathrm{~kg} / \mathrm{m}^{2}$ の条件において, 半径 $40 \mathrm{~mm}$ の模型を用いて撮影した弓状衝撃波のシュリーレン写真 の 1 例を示す.

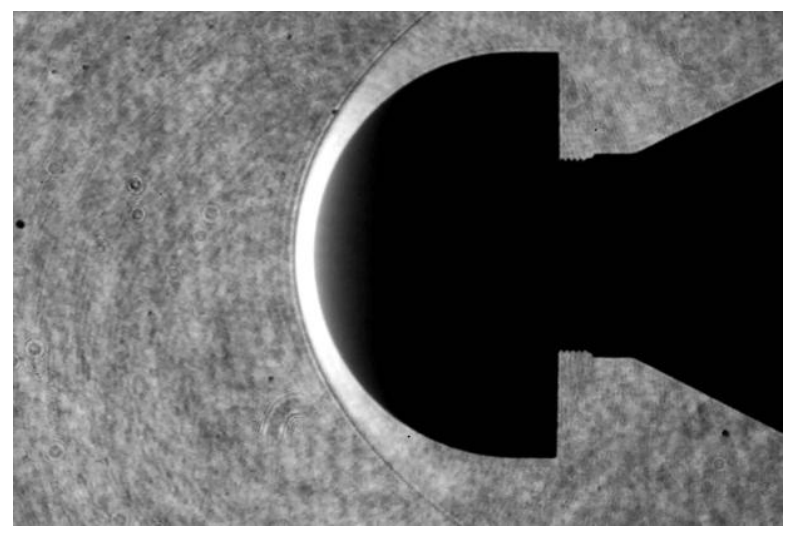

Fig. 6 Schlieren photograph around 40mm hemisphere model at $10 \mathrm{MJ} / \mathrm{kg}$ in stagnation enthalpy and $20 \mathrm{MPa}$ in stagnation pressure.

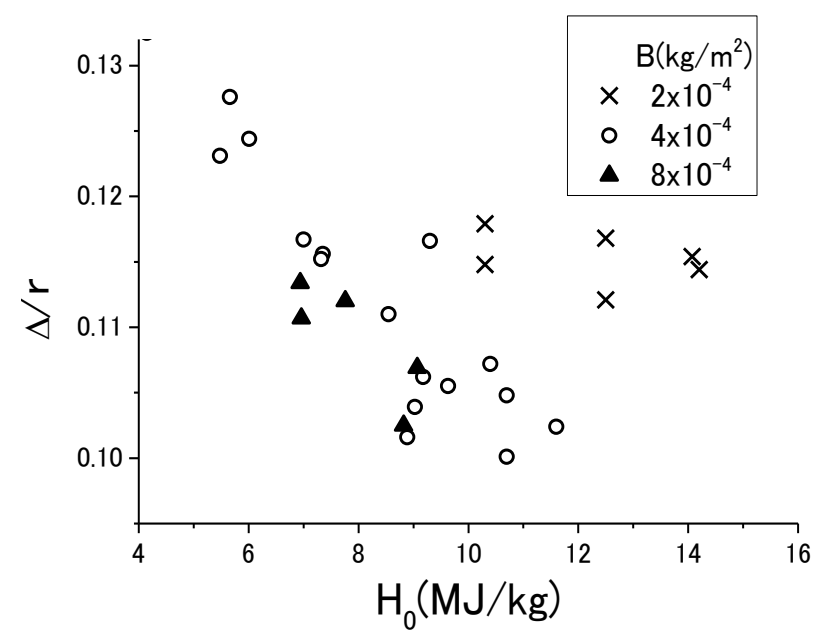

Fig. 7 Shock stand-off distance measured in the HIEST vs. stagnation enthalpy.

表 2 のノナル条件について行ったすべての試験について, シュリーレン写真から計測した衝撃波離脱距離を 模型の半径で無次元化し, 淀み点エンタルピを横軸にとって図 7 に示す. 図 5 と同様に衝撃波離脱距離の計測結果 をバイナリースケーリングパラメータごとにグループ分けし，×，○およびムはそれぞれバイナリースケーリン グパラメータ $\mathrm{B}=2 \times 10^{-4}, 4 \times 10^{-4} \mathrm{~kg} / \mathrm{m}^{2}$, および $8 \times 10^{-4} \mathrm{~kg} / \mathrm{m}^{2}$ の場合の計測結果を示す. いずれのバイナリースケーリ ングパラメータのグループにおいても, 定性的には淀み点エンタルピの増加とともに衝撃波離脱距離が短くなる 傾向が見られる.ノミナルの淀み点エンタルピの設定が $8 \mathrm{MJ} / \mathrm{kg}$ の一つだけだった $\mathrm{B}=8 \times 10^{-4} \mathrm{~kg} / \mathrm{m}^{2}$ のグループでも, 先述の通り淀み点圧力の設定によって 7.0MJ/kg から 9.0MJ/kg まで変化する実測の淀み点エンタルピに対して, 衝 撃波離脱距離の計測結果が減少している.この淀み点エンタルピに対する衝撃波離脱距離の基本的な傾向につい ては, 衝撃波直後の温度上昇による効果が主たる要因であると考えられる. 式(5)および(6)の密度勾配関数より, 理論的には, 衝撃波直後の温度 $\mathrm{T}_{\mathrm{s}}$ が上昇寸ると指数関数的に解離反応速度が上がって下流の密度増加を促進し, 衝撃波離脱距離を減少させる.ただし, 衝撃波離脱距離は淀み点エンタルピに対しては一つの傾向にまとまらず, バイナリースケーリングパラメータなど温度以外の効果が無視できないことが計測結果から明らかである. 大き なバイナリースケーリングパラメータの場合ほど, 淀み点エンタルピに対して衝撃波離脱距離の減少が大きいこ とが図 7 よりわかる.これは, 理論的には式(5)および(6)の密度勾配関数に示すように, バイナリースケーリング 
パラメータに比例して解離反応速度が上昇して密度増加を促進し, 衝撃波離脱距離の減少を大きくするためと考 えられる. 次節では, 主流の酸素原子の影響を検証する前段階として,衝撃波離脱距離に対するバイナリースケー リングパラメータの効果について考察する.

\section{$6 \cdot 2$ バイナリスケーリングパラメータの効果}

密度勾配関数との相関から衝撃波離脱距離に対するバイナリースケーリングパラメータの効果を考察するため, まず密度勾配以外に衝撃波離脱距離に関わるもう一つの要因である衝撃波前後の密度比で以下のように衝撃波離 脱距離を標準化する.

$$
\Pi \equiv \frac{\rho_{s}}{\rho_{\infty}} \frac{\Delta}{r}
$$

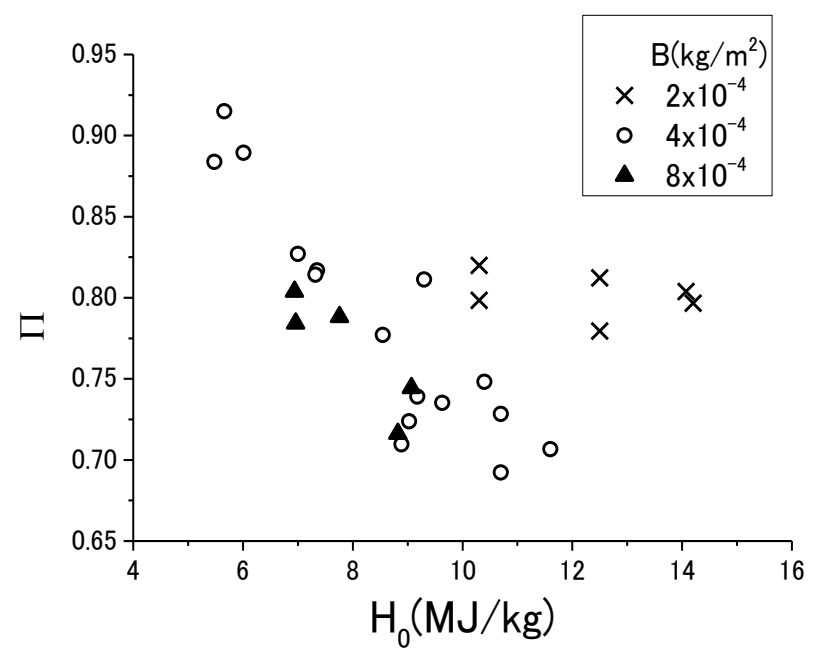

Fig. 8 Shock stand-off distance normalized by density jump across shock wave vs. stagnation enthalpy.

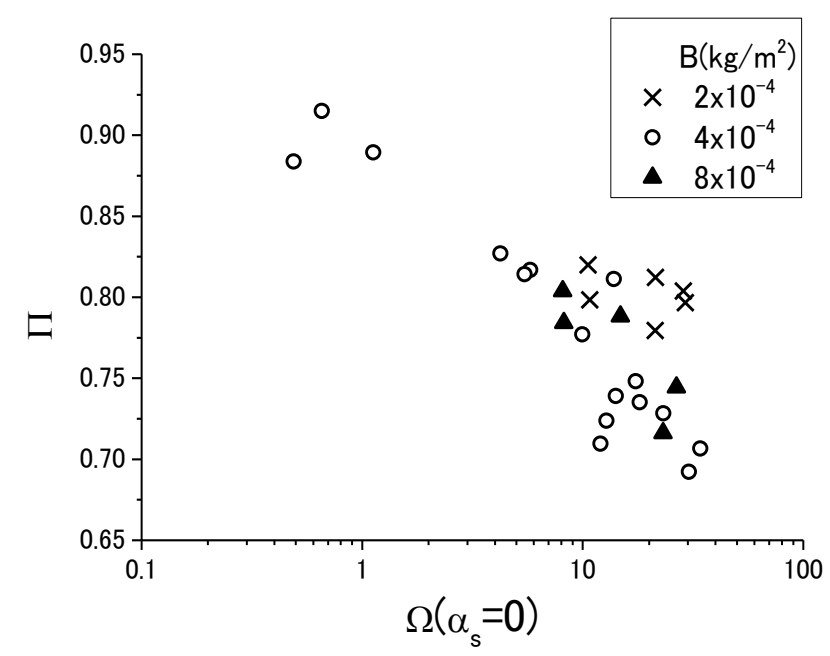

Fig. 9 Normalized shock stand-off distance vs. density function without free stream oxygen atom.

図 8 は, 衝撃波前後の密度比で標準化した衝撃波離脱距離を示す. 式(2)に示すように, 衝撃波前後の密度比に も主流の酸素原子の影響が含まれるが, 反応が凍結状態の衝撃波跳躍過程においてはわずかに比熱比を変える効 果しかなく, 図 7 との比較から明らかなように影響は小さい. 衝撃波離脱距離に対するバイナリースケーリング パラメータの効果については, 式(5)および(6)において $\alpha_{\mathrm{s}}=0$ とおいて主流の酸素原子の影響を無視した密度勾配 関数に対する衝撃波離脱距離の計測結果の傾向を, 図 8 の淀み点エンタルピのみに対する傾向と比較して考察す る. 図9は, 式(5)および(6)において, $\alpha_{s}=0$ として計算した密度勾配関数を横軸にとって衝撃波離脱距離をプロット したものである. 密度勾配関数を通してバイナリースケーリングパラメータも相関パラメータとして導入するこ とにより, 図 8 の淀み点エンタルピのみに対する傾向と比べると明らかに計測結果の傾向の分散が小さくなった. 図 8 に見られたバイナリースケーリングパラメータごとの衝撃波離脱距離の減少勾配の違いが密度勾配関数によ って大幅に補正された. 主流の酸素原子質量分率が比較的低めで影響が小さいと考えられる $\mathrm{B}=4 \times 10^{-4} \mathrm{~kg} / \mathrm{m}^{2}$ と $8 \times 10^{-4} \mathrm{~kg} / \mathrm{m}^{2}$ の場合は特に傾向の一致が良好である.このことから，式(5)および(6)に導出した理論通りのバイナ リースケーリングパラメータの効果, 寸なわちバイナリースケーリングパラメータに比例して解離反応速度が上 昇し, 密度増加を促進して衝撃波離脱距離の減少勾配を大きくするという効果が検証された. 一方, 比較的主流 の酸素原子質量分率が多い $\mathrm{B}=2 \times 10^{-4} \mathrm{~kg} / \mathrm{m}^{2}$ のグループでは, より低密度条件ほど衝撃波離脱距離が長くなる方向 一傾向のずれが残る.これは理論的には, 式(5)および(6)より, 主流の酸素原子が解離反応速度を低下させて密 度増加を抑制するためと考えられ，次節において検証する。 


\section{$6 \cdot 3$ 主流の酸素原子の効果}

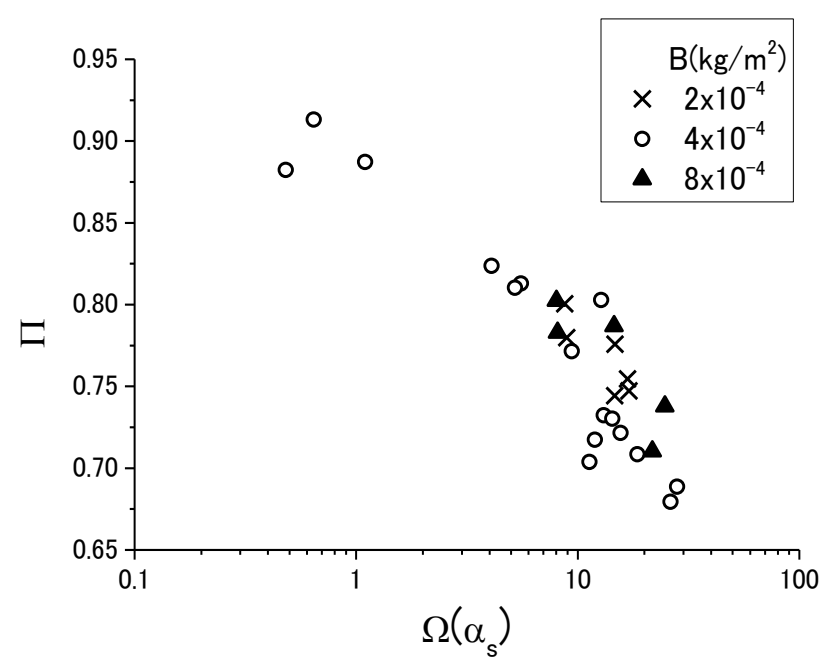

Fig. 10 Normalized shock stand-off distance vs. density function with free stream oxygen atom.

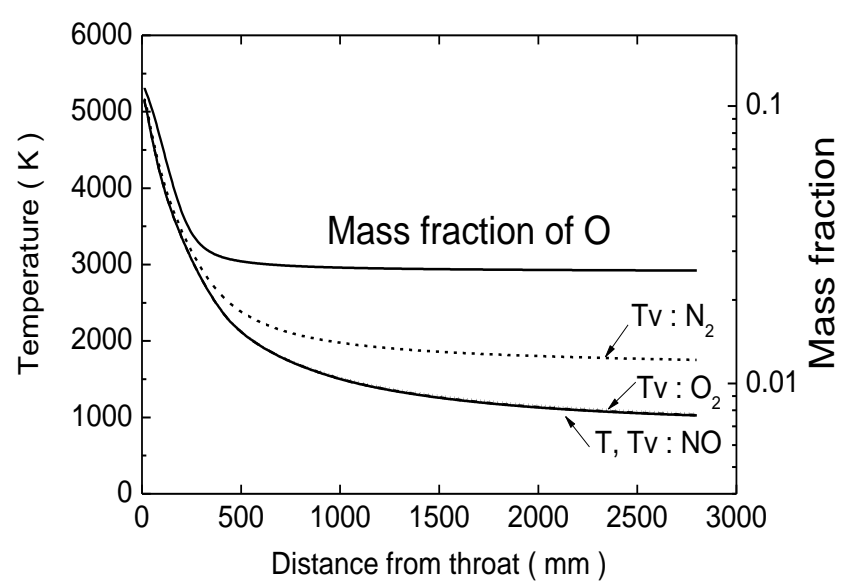

Fig. 11 Thermally and chemically nonequilibrium nozzle flow analysis.

さて本研究の主題である衝撃波離脱距離に対する主流の酸素原子の効果について, 主流の酸素原子を考慮した 密度勾配関数に対する衝撃波離脱距離の計測結果の傾向を, 図 9 の主流の酸素原子を無視した場合の傾向と比較 して考察する. 図 10 は, 準 1 次元化学非平衡解析で予測した主流の酸素原子の質量分率 $\alpha_{\mathrm{s}}$ を用いて式(5)および(6) より計算した密度勾配関数を横軸にとって, 衝撃波離脱距離の計測結果をプロットしたものである. 図 9 の主流 の酸素原子を無視した場合の傾向との比較から明らかなように, 密度勾配関数を通して主流の酸素原子も相関パ ラメータとして導入することにより, $\mathrm{B}=2 \times 10^{-4} \mathrm{~kg} / \mathrm{m}^{2}$ の場合も含めてすべての計測結果が一つの傾向にまとまった. 図 9 に見られた, 主流の酸素原子が多めの低密度条件ほど衝撃波離脱距離が長くなる傾向が, 準 1 次元化学非平 衡流解析の予測值 $\alpha_{\mathrm{s}}$ を用いて計算した密度勾配関数によってほぼ完全に補正された。詳細に見れば, $\mathrm{B}=4 \times 10^{-4} \mathrm{~kg} / \mathrm{m}^{2}$ と $8 \times 10^{-4} \mathrm{~kg} / \mathrm{m}^{2}$ の場合の計測結果もより緊密にまとまったことがわかる。このことから，式(5)およ び(6)に導出した主流の酸素原子の理論通りの効果, 寸なわち解離反応速度を低下させて密度増加を抑制すること で衝撃波離脱距離を長くする効果が検証された. 同時に, 準 1 次元化学非平衡流解析による主流の酸素原子の予 測值が妥当であることも検証された. なお, 熱平衡を仮定した数值解析でも妥当な酸素原子の予測值が得られた 理由は, 図 11 に示寸熱非平衡も考慮したノズル流れの解析結果 ${ }^{(8)}$ に見られるように, 各振動温度の緩和過程に差 が生じて熱的非平衡性が顕著になる前の熱平衡状態において, 酸素原子の再結合反応の凍結が起こるためと考え られる。

\section{7. 結言}

直接計測が困難な高温衝撃風洞流れに残留する未再結合の酸素原子の同定を目的として, 主流の酸素原子の存 在に敏感な衝撃波離脱距離を計測し，主流の酸素原子の効果に関する理論および関連する数值解析の妥当性を検 証した. 衝撃波離脱距離を決定する主要因として, 淀み点エンタルピ,バイナリースケーリングパラメータおよ び主流の酸素原子をパラメータとする密度勾配関数を導出し, 準 1 次元化学非平衡流解析による主流の酸素原子 の予測值を用いて密度勾配関数を計算し, 衝撃波離脱距離の計測結果と良好な相関が得られた. HIEST において コントロール可能な試験パラメータを広範囲に設定し, 衝撃波離脱距離に係る相関パラメータの独立性を確保す ることによって, 理論および数值解析の妥当性を検証するとともに HIEST の主流に残留する酸素原子の質量分率 を同定することができた. その結果, HIEST においては, 淀み点圧力 $20 \mathrm{MPa}$ 以下かつ淀み点エンタルピ $10 \mathrm{MJ} / \mathrm{kg}$ 
以上の低密度条件の試験では主流の酸素原子の影響が顕著になるが，それ以外の条件では影響が小さいことがわ かった.

\section{文献}

(1) Itoh,K., Ueda,S., Komuro,T., Sato,K., Takahashi,M., Miyajima,H., Design and Construction of HIEST (High Enthalpy Shock Tunnel), Proceedings of International Conference on Fluid Engineering, Vol. I, (1997), pp. 353-358.

(2) Wen, C.Y. and Hornung, H.G., Non-equilibrium Dissociating Flow Over Spheres, Journal of Fluid Mechanics, Vol. 299 (1995), pp. 389-405.

(3) Lordi,J.A., Mates,R.,E., Moselle,J.,R., Computer Program for the Numerical Solution of Nonequilibrium Expansions of Reacting Gas Mixtures, NASA-CR-472 (1965)

(4) Van Dyke, M.D., The Supersonic Blunt-Body Problem-Review and Extension, Journal of the Aero/Space Sciences, Vol.25,(1958), pp.485-496.

(5) Olivier, H., A Theoretical Model for the Shock Stand-off Distance in Frozen and Equilibrium Flows, Journal of Fluid Mechanics, Vol.413, (2000), pp.345-353.

(6) Lighthill, M.J., Dynamics of a Dissociating Gas. Part I Equilibrium Flow, Journal of Fluid Mechanicsr, Vol.2,(1979), pp.1-32.

(7) Hornung, H.G., Non-equilibrium Dissociating Nitrogen Flow over Spheres and Circular Cylinders, Journal of Fluid Mechanics, Vol.53, part 1,(1972), pp.149-176.

(8) Takahashi,M., Kodera,M., Itoh,K., Komuro,T., Sato, K., Tanno,H., Influence of Thermal Non-equilibrium on Nozzle Flow Condition of High Enthalpy Shock Tunnel HIEST, Proceedings of $16^{\text {th }}$ International Space Plane and Hypersonic Systems and Technologies Conference, AIAA-7267, (2009)

(9) Hashimoto,T., Komuro,T., Sato,K., Itoh,K., Experimental Investigation of Shock Stand-off Distance on Spheres in Hypersonic Nozzle Flows, Proceedings of $26^{\text {th }}$ International Symposium on Shock Waves, Vol.12 (2002), pp. 93-98.

(10) Belouaggadia,N., Olivier,H., Brun,R., Numerical and Theoretical Study of the Shock Stand-off Distance in Non-equilibrium Flows, Journal of Fluid Mechanics, Vol.607, (2008), pp. 167-197.

(11) Freeman, N.C., Non-equilibrium Flow of an Ideal Dissociating Gas, Journal of Fluid Mechanics, Vol.4, (1958), pp.407-425.

(12) Freeman, N.C., On the Theory of Hypersonic Flow Past Plane and Axially Symmetric Bluff Bodies, Journal of Fluid Mechanics, Vol.1, (1956), pp.366-387. 